
October 1940

\title{
DETERMINATION OF NONVOLATILE MATTER AND THE CALCULATION OF "CUT" OF SHELLAC VARNISH
}

\author{
By Charles C. Hartman
}

\begin{abstract}
Using the three recognized methods for determining the nonvolatile content of shellac varnish, 70 varnishes, made by cutting 33 dry orange shellacs and 6 dry bleached shellacs in 5 different solvents, were examined and a summary of the results was prepared. This summary shows: (1) That the method given in Federal Specification TT-V-91 is most convenient and simple in operation, and that the results obtained thereby are in closer agreement than those obtained by the methods given in the specifications of the American Society for Testing Materials and of the U. S. Shellac Importers Association, Inc.; (2) That the presence of volatile matter in dry shellac and the use of solvents with high end points influence, decidedly, the nonvolatile determination; and (3) That, in calculating the "cut" of a shellac varnish, a positive correction must be made to the percentage of nonvolatile residue for the volatile content of the dry shellac determined at $105^{\circ} \mathrm{C}$.
\end{abstract}

CONTENTS

Page

I. Introduction

1. Shellac _... 396

2. Volatile components _... 398

III. Preparation of experimental varnishes

IV. Determination of nonvolatile content__.. 398

V. Discussion of results and conclusions

VI. References_.

\section{INTRODUCTION}

By the term "shellac varnish" is understood the material defined by the American Society for Testing Materials [1] ${ }^{1}$ as "A solution or 'cut' of a specified grade of pure orange shellac or dry bleached shellac (the manufactured products from the secretion of the Laccifer Lacca Kerr with no added resin, copal or other adulterants; in the most commonly used solvent, 95 percent (190 proof) specially denatured alcohol, Formula 1 of the U. S. Internal Revenue Bureau or in other specified denatured alcohol or solvent." The refinement of the natural resin to produce the orange shellac used in varnish making is largely a cleaning process to remove excessive dirt and sticks [2]. Bleached shellac is obtained by treating orange shellac with chemical agents to remove the natural dye. Various grades of orange and bleached. shellac varnish are available in "cuts" ranging from 3 to 8 pounds. In the trade, the word "cut" indicates the pounds of shellac resin added to each gallon of solvent. The manufacturer's label on the

\footnotetext{
1 Figures in brackets indicate the literature references at the end of this paper.
} 
container usually states the cut of the shellac varnish; for example, "4 pounds per gallon" or "4-pound cut." This statement does not mean that the gallon of varnish contains 4 pounds of shellac resin but indicates that 4 pounds of "dry" 2 shellac was dissolved, or cut, in 1 gallon of solvent. About 1.4 gallons of varnish results, and hence 1 gallon of this varnish contains slightly less than 3 pounds of the dry shellac-equivalent approximately to 37 percent by weight.

The amount of shellac in the varnish is determined by evaporating the solvent under specified conditions and assuming that what is left is shellac. Three procedures are now in use for this purpose: those of the United States Shellac Importers Association (abbreviated USSIA) [1], of the American Society for Testing Materials (ASTM) [3], and of the United States Government (FS for Federal specification) [4]. In each procedure a 1.0 - to $1.5-\mathrm{g}$ sample of varnish is weighed into a shallow metal dish and is heated in an oven at a constant temperature of about $105^{\circ} \mathrm{C}$ for a specified period of time and again weighed. Differences in the methods are shown in table 1 . It was the purpose of the tests reported in this paper to ascertain how well the amounts of shellac found in varnishes by each of the three methods agree with the amounts measured when the varnishes are manufactured. Briefly, the method of study consisted in dissolving weighed quantities of numerous grades of shellac in different solvents, and determining the nonvolatile matter in the resultant varnishes by the three methods in question.

TABLE 1.-Differences in methods

\begin{tabular}{|c|c|c|c|}
\hline Method & $\begin{array}{l}\text { U. S. Shellac Importers } \\
\text { Association, Inc. }\end{array}$ & $\begin{array}{l}\text { American Society for } \\
\text { Testing Materials }\end{array}$ & Federal specification \\
\hline Receptacle & $\begin{array}{l}\text { Tin-foil dish approxi. } \\
\text { mately } 11 / 4 \text { in. }(3.1 \mathrm{~cm}) \\
\text { in height and } 21 / 2 \mathrm{in} . \\
(6.3 \mathrm{~cm}) \text { in diameter. }\end{array}$ & $\begin{array}{l}\text { Friction-top can plug ap- } \\
\text { proximately } 5 / 16 \text { in. }(0.8 \\
\text { cm) in height and } 3.2 \\
\text { in. }(8 \mathrm{~cm}) \text { in diameter. }\end{array}$ & $\begin{array}{l}\text { Friction-top can plug ap- } \\
\text { proximately } 5 / 6 \text { in. }(0.8 \\
\text { cm) in height and } 3.2 \\
\text { in. }(8 \mathrm{~cm}) \text { in diameter. }\end{array}$ \\
\hline Weight of sample....... & About $1 \mathrm{~g}$ & Not more than $1.5 \mathrm{~g}$ & 1 to $1.5 \mathrm{~g}$. \\
\hline $\begin{array}{l}\text { Addition of specially } \\
\text { denatured alcohol } \\
\text { (formula 1). }\end{array}$ & $\begin{array}{l}1 \text { ml to "cuts" heavier } \\
\text { than } 5 \text { pounds. }\end{array}$ & Approximately $2 \mathrm{~g} . .$. & Do. \\
\hline $\begin{array}{l}\text { Treatment before heat- } \\
\text { ing. }\end{array}$ & $\begin{array}{l}\text { Sand and varnish mixed } \\
\text { thoroughly with glass } \\
\text { rod. }\end{array}$ & $\begin{array}{l}\text { Sand and varnish mixed } \\
\text { thoroughly with glass } \\
\text { rod. }\end{array}$ & Do. \\
\hline Temperature at which & $105^{\circ} \pm 2^{\circ} \mathrm{C}$ & $105^{\circ} \pm 2^{\circ} \mathrm{C}$ & $105^{\circ}$ to $110^{\circ} \mathrm{C} . \mathrm{a}$ \\
\hline Heating period. - & 1 hour & 3 hours. & 3 hours. \\
\hline
\end{tabular}
C.

a The revision of this specification now in the process of being printed specifies a temperature of $105^{\circ} \pm 2^{\circ}$

\section{MATERIALS USED}

\section{SHELLAC}

Thirty-three samples of orage shellac of thirty different commercial brands or grades, four samples of "regular" and two samples of "refined" bleached shellac were used. Since determinations were to be made of the nonvolatile residue, a knowledge of the amount of volatile matter in the original shellac was essential to an interpretation of the results. The method most commonly used for determining volatile matter-usually considered to be moisture-is to heat a finely ground sample in a shallow dish to constant weight at a

2 With ordinary shellac, the term "dry" refers to the shellac as sold. 
TABLe 2.-Volatile content of "dry" shellacs

\begin{tabular}{|c|c|c|}
\hline \multirow{2}{*}{ Identification number } & \multicolumn{2}{|c|}{ Loss of weight at- } \\
\hline & $\begin{array}{l}41^{\circ} \pm 2^{\circ} \mathrm{C} \\
(24 \mathrm{hr})\end{array}$ & $\begin{array}{c}105^{\circ} \pm 2^{\circ} \mathrm{C} \\
(3 \mathrm{hr})\end{array}$ \\
\hline \multicolumn{3}{|c|}{ 1. ORANGE SHELLAC } \\
\hline $\begin{array}{l}1 \text { (a) } 1 \text { (b) } \\
1 \text { (c) } \\
2 \text { (b) }\end{array}$ & $\begin{array}{c}\text { Percent } \\
0.38 \\
.41 \\
.54 \\
.26 \\
.52\end{array}$ & $\begin{array}{c}\text { Percent } \\
1.32 \\
1.31 \\
1.42 \\
1.17 \\
1.31\end{array}$ \\
\hline $\begin{array}{ll}3 \\
4 \\
5 \\
6 \\
7\end{array}$ & $\begin{array}{l}.45 \\
.48 \\
.36 \\
.56 \\
.68\end{array}$ & $\begin{array}{l}\text { 1. } 50 \\
1.52 \\
1.36 \\
1.38 \\
1.45\end{array}$ \\
\hline $\begin{array}{l}8 \\
9 \\
10 \\
11 \\
12 \ldots\end{array}$ & $\begin{array}{l}.58 \\
.49 \\
.34 \\
.37 \\
.38\end{array}$ & $\begin{array}{l}\text { 1. } 40 \\
\text { 1. } 37 \\
1.30 \\
1.35 \\
1.34\end{array}$ \\
\hline $\begin{array}{l}13 \\
14 \\
15 \\
16 \\
17\end{array}$ & $\begin{array}{l}.38 \\
.31 \\
.34 \\
.44 \\
.44\end{array}$ & $\begin{array}{l}1.42 \\
1.43 \\
1.44 \\
1.36 \\
1.41\end{array}$ \\
\hline $\begin{array}{l}18 \\
19 \\
21 \\
22\end{array}$ & $\begin{array}{l}.59 \\
.52 \\
.60 \\
.29 \\
.45\end{array}$ & $\begin{array}{l}1.52 \\
1.48 \\
1.56 \\
1.58 \\
1.58\end{array}$ \\
\hline $\begin{array}{l}23 \\
24 \\
25 \\
26 \\
27\end{array}$ & $\begin{array}{l}.82 \\
.86 \\
.82 \\
.79 \\
.70\end{array}$ & $\begin{array}{l}1.34 \\
1.44 \\
1.37 \\
1.27 \\
1.39\end{array}$ \\
\hline $\begin{array}{l}28, \ldots+1 \\
29 \\
30\end{array}$ & $\begin{array}{l}.81 \\
.70 \\
.76\end{array}$ & $\begin{array}{l}1.44 \\
1.40 \\
1.42\end{array}$ \\
\hline $\begin{array}{l}\text { Average } \\
\text { Avg deviation } \\
\text { Max minus min }\end{array}$ & $\begin{array}{r}0.53 \\
.15 \\
.60\end{array}$ & $\begin{array}{l}1.41 \\
.07 \\
.41\end{array}$ \\
\hline \multicolumn{3}{|c|}{ 2. BLEACHED SHELLAC (REGULAR) } \\
\hline $\begin{array}{l}31 \\
32 \\
33 \\
34\end{array}$ & $\begin{array}{l}0.75 \\
4.77 \\
2.04 \\
4.28\end{array}$ & $\begin{array}{l}1.93 \\
5.69 \\
3.03 \\
4.97\end{array}$ \\
\hline \multicolumn{3}{|c|}{ 3. BLEACHED SHELLAC (REFINED) } \\
\hline 35 & $\begin{array}{l}2.48 \\
5.54\end{array}$ & $\begin{array}{l}\text { 3. } 31 \\
6.12\end{array}$ \\
\hline $\begin{array}{l}\text { A verage, } 2 \text { and } 3 \\
\text { A vg deviation, } 2 \text { and }\end{array}$ & 3.31 & 4.18 \\
\hline $\begin{array}{l}\text { Max minus min, } 2 \\
\text { and } 3 \ldots . .\end{array}$ & $\begin{array}{l}1.54 \\
4.79\end{array}$ & $\begin{array}{l}1.25 \\
4.19\end{array}$ \\
\hline
\end{tabular}

1 Letters in parentheses indicate samples of the same grade of shellac.

temperature of $41^{\circ} \pm 2^{\circ} \mathrm{C}$. However, it is known that the loss increases with the temperature of drying, and since the determination of the nonvolatile content of the varnish is made at $105^{\circ} \mathrm{C}$, the loss at this temperature seemed more informative. Consequently, samples 
of 0.25 to $1.00 \mathrm{~g}$ of the finely ground shellac in friction-top can plugs were heated at $105^{\circ} \mathrm{C}$ for 3 hours. In table 2 these results are compared with those found by heating at $41^{\circ} \mathrm{C}$ for 24 hours. $^{3}$

\section{VOLATILE COMPONENTS}

The solvents used in cutting the dry shellacs were those authorized for this purpose by the United States Bureau of Internal Revenue [5] as follows:

(1) Formula 1.-100 gallons of ethyl alcohol (190 proof) denatured with 5 gallons of approved wood alcohol.

(2) Formula 1A.4-100 gallons of ethyl alcohol (190 proof) denatured with 10 gallons of denaturing grade isopropanol and 0.5 gallon of commercial alpha-terpinol.

(3) Formula 44A (1).4-100 gallons of ethyl alcohol (190 proof) denatured with 4 gallons of approved wood alcohol and 10 gallons of normal butyl alcohol.

(4) Formula 44A (2). -100 gallons of ethyl alcohol (190 proof) denatured with 4 gallons of approved wood alcohol and 10 gallons of amyl alcohol (synthetic or natural).

(5) Proprietary solvent.-Made to standard Alcohol Tax Unit formula: 100 gallons of specially denatured alcohol formula 1, 5 gallons of denatured ethyl acetate, and 1 gallon of aviation gasoline.

\section{PREPARATION OF EXPERIMENTAL VARNISHES}

The orange shellacs were ground to pass a 40 -mesh sieve, and the bleached shellacs were powdered. A portion of each shellac after thorough mixing, was weighed accurately in a tared glass container, the solvent was added, and the container was stoppered tightly and reweighed. The varnishes were stored at room temperature for several days and, to insure complete solution, were shaken periodically. The following is a list of the solutions made:

(1) 30 orange and 6 bleached shellacs in alcohol denatured according to formula 1.

(2) 5 orange shellacs in alcohol denatured according to formula $1 \mathrm{~A}$.

(3) 5 orange shellacs in alcohol denatured according to formula $44 \mathrm{~A}(1)$.

(4) 4 orange shellacs in alcohol denatured according to formula $44 \mathrm{~A}(2)$.

(5) 6 orange and 6 bleached shellacs in the proprietary solvent.

(6) 4 orange shellacs (previously heated to $41^{\circ} \pm 2^{\circ} \mathrm{C}$ for 24 hours) in alcohol denatured according to formula 1.

(7) 4 orange shellacs (previously heated at $41^{\circ} \pm 2^{\circ} \mathrm{C}$ for 24 hours) in the proprietary solvent.

\section{DETERMINATION OF NONVOLATILE CONTENT}

Three determinations of the nonvolatile content of each varnish were made by each of the three methods mentioned in the introduction. The heating was done in an electric oven which had four revolving shelves. The three receptacles containing the samples of any

\footnotetext{
33 to 6 hours is the time usually employed for the test at $41^{\circ} \mathrm{C}$.

4 Since this work was undertaken a revision of the regulations has been issued. Formulas $1 \mathrm{~A}$ and $44 \mathrm{~A}(2)$ have been discontinued. Formula 44A (1) has been changed to formula 44 which reads: "To every 100 gallons of ethyl alcohol (190 proof) add 10 gallons of normal butyl alcohol."
} 
one varnish to be tested by the three methods were placed on the same shelf, and the three tests were begun simultaneously. On different days the tests of the same varnish were repeated, with the three specimens placed on a different shelf each time.

The FS method gave the best agreement between triplicate tests. This is shown by the summary in table 3 .

The weighed residues, and the same corrected in each case by adding the loss of weight at $105^{\circ} \mathrm{C}$ of the dry shellac used in making the varnish, were both expressed as percentages of the weights of shellac dissolved. A complete tabulation of the results, expressed on this percentage basis, is too long to be included in this paper, but table 4 summarizes them as the minimum, maximum, and average for each group of varnishes. The "corrected" percentage would have been 100 in each case if all the solvent had evaporated and the residue had been brought to the same state as that of the dry shellac after being heated at the same temperature.

TABLE 3.-Agreement between results obtained in triplicate determinations of nonvolatile residues in 70 varnishes

\begin{tabular}{|c|c|c|c|}
\hline Method & $\begin{array}{c}\text { Federal } \\
\text { specification }\end{array}$ & $\begin{array}{l}\text { American } \\
\text { Society for } \\
\text { Testing } \\
\text { Materials }\end{array}$ & $\begin{array}{l}\text { U. S. Shellac } \\
\text { Importers } \\
\text { Association, } \\
\text { Inc. }\end{array}$ \\
\hline $\begin{array}{l}\text { Minimum difference between the highest and lowest results } \\
\text { obtained in any triplicate set } \\
\text { Maximum difference between the highest and lowest results } \\
\text { obtained in any triplicate set. } \\
\text { Average of differences between the highest and lowest results } \\
\text { obtained in all the triplicate sets.... } \\
\text { Number of triplicate determinations in which the difference } \\
\text { between the highest and lowest results exceeded } 0.34 \% \text {-..- }\end{array}$ & $\begin{array}{l}0.02 \\
.58 \\
.19 \\
5\end{array}$ & $\begin{array}{r}0.05 \\
.77 \\
.25 \\
25\end{array}$ & $\begin{array}{l}0.07 \\
1.12 \\
0.34 \\
32\end{array}$ \\
\hline
\end{tabular}

The USSIA method gave high values consistently, probably because of insufficient time of heating and consequent retention of solvent. The FS and ASTM methods also gave high values for the varnishes which contained solvent formulas 44A (1) and 44A (2). Both of these formulas contain appreciable amounts of solvents with high "end points," ${ }^{5}$ and again, retention of solvent seems to explain the results.

5 The term "end point" refers to the temperature at which the last portion of the solvent mixture evapo* rates in a distillation test. In this work, $110^{\circ} \mathrm{C}$ is chosen as a reasonable minimum temperature. 
TABLE 4.-Minimum, maximum, and average percentages of nonvolatile residues recovered from the shellac varnishes by three different methods

\begin{tabular}{|c|c|c|c|c|c|c|c|c|}
\hline \multirow[b]{2}{*}{ Solvent formula (see p. 398 of text) } & \multirow[b]{2}{*}{ Type of shellac varnish } & \multirow[b]{2}{*}{$\begin{array}{c}\text { Number of } \\
\text { varnishes } \\
\text { represented }\end{array}$} & \multirow{2}{*}{$\begin{array}{c}\text { A verage } \\
\text { percentage } \\
\text { of volatile } \\
\text { matter } \\
\text { found in the } \\
\text { dry shellac } \\
\text { at } 105^{\circ} \mathrm{C}\end{array}$} & \multirow[b]{2}{*}{ Method } & \multicolumn{3}{|c|}{ Percentage of recovery } & \multirow{2}{*}{$\begin{array}{l}\text { A verage } \\
\text { percentage } \\
\text { of recovery, } \\
\text { corrected } \\
\text { for percent- } \\
\text { age of vola- } \\
\text { tile matter } \\
\text { in the dry } \\
\text { shellac at } \\
105^{\circ} \mathrm{C}\end{array}$} \\
\hline & & & & & Minimum & Maximum & Average & \\
\hline 1.... & Orange_... & 30 & $\begin{array}{ll}\% & \\
& 1.4\end{array}$ & $\left\{\begin{array}{l}\text { FS } \\
\text { ASTM } \\
\text { USSIA }\end{array}\right.$ & $\begin{array}{r}\%_{97.5} \\
97.5 \\
97.7\end{array}$ & $\begin{array}{r}\% \\
99.2 \\
99.6 \\
100.8\end{array}$ & $\begin{array}{r}\%_{98.4} \\
98.5 \\
99.3\end{array}$ & $\begin{array}{r}99.8 \\
99.9 \\
100.7\end{array}$ \\
\hline Proprietary... & -......... & 6 & 1.3 & $\left\{\begin{array}{l}\text { FS } \\
\text { ASTM } \\
\text { USSIA }\end{array}\right.$ & $\begin{array}{l}97.7 \\
97.9 \\
98.6\end{array}$ & $\begin{array}{l}99.5 \\
99.2 \\
99.7\end{array}$ & $\begin{array}{l}98.8 \\
98.7 \\
99.3\end{array}$ & $\begin{array}{l}100.1 \\
100.0 \\
100.6\end{array}$ \\
\hline 1A... & -......... & 5 & 1.4 & $\left\{\begin{array}{l}\text { FS } \\
\text { ASTM } \\
\text { USSIA }\end{array}\right.$ & $\begin{array}{l}98.2 \\
98.2 \\
98.7\end{array}$ & $\begin{array}{r}99.2 \\
99.1 \\
100.2\end{array}$ & $\begin{array}{l}98.8 \\
98.6 \\
99.3\end{array}$ & $\begin{array}{l}100.2 \\
100.0 \\
100.7\end{array}$ \\
\hline $44 \mathrm{~A}(1) \ldots$ & ....... do & 5 & 1.4 & $\left\{\begin{array}{l}\text { FS } \\
\text { ASTM- } \\
\text { USSIA }\end{array}\right.$ & $\begin{array}{l}98.6 \\
98.6 \\
99.7\end{array}$ & $\begin{array}{r}101.1 \\
99.9 \\
101.0\end{array}$ & $\begin{array}{r}99.9 \\
99.3 \\
100.5\end{array}$ & $\begin{array}{l}101.3 \\
100.7 \\
101.9\end{array}$ \\
\hline $44 \mathrm{~A}(2) \ldots$ & -........ & 4 & 1.6 & $\left\{\begin{array}{l}\text { FS } \\
\text { ASTM- } \\
\text { USSIA }\end{array}\right.$ & $\begin{array}{r}98.9 \\
98.4 \\
100.0\end{array}$ & $\begin{array}{r}99.6 \\
99.2 \\
100.7\end{array}$ & $\begin{array}{r}99.3 \\
98.9 \\
100.3\end{array}$ & $\begin{array}{l}100.9 \\
100.5 \\
101.9\end{array}$ \\
\hline 1..... & Bleached.- & 6 & 4.2 & $\left\{\begin{array}{l}\text { FS } \\
\text { ASTM } \\
\text { USSIA }\end{array}\right.$ & $\begin{array}{l}93.7 \\
93.8 \\
95.3\end{array}$ & $\begin{array}{l}98.7 \\
98.3 \\
99.5\end{array}$ & $\begin{array}{l}95.7 \\
95.7 \\
96.8\end{array}$ & $\begin{array}{r}99.9 \\
99.9 \\
101.0\end{array}$ \\
\hline Proprietary & ................ & 6 & 4.2 & $\left\{\begin{array}{l}\text { FS } \\
\text { ASTM- } \\
\text { USSIA }\end{array}\right.$ & $\begin{array}{l}93.3 \\
93.5 \\
94.8\end{array}$ & $\begin{array}{l}98.0 \\
97.8 \\
98.8\end{array}$ & $\begin{array}{l}95.3 \\
95.4 \\
96.7\end{array}$ & $\begin{array}{r}99.5 \\
99.6 \\
100.9\end{array}$ \\
\hline
\end{tabular}




\section{DISCUSSION OF RESULTS AND CONCLUSIONS}

In table 2 the volatile portion of dry shellac is listed as determined at $41^{\circ} \mathrm{C}$ and at $105^{\circ} \mathrm{C}$. The considerable variation in the results obtained at $41^{\circ} \mathrm{C}$ can be attributed not only to the variable moisture content of the original samples because of day to day differences in the relative humidities of the room in which they were stored but also to the fact that the relative humidity of the drying oven at a temperature of $41^{\circ} \mathrm{C}$ will vary over a wide range according to the relative humidity in the room at the time of the determination. The better agreement in the values obtained at $105^{\circ} \mathrm{C}$ for the orange shellacs can be attributed to the practical elimination of the relative humidity of the oven as a factor in the results obtained.

When corrected for the volatile material in the shellac, the ASTM and FS methods for nonvolatile material in the varnish agree well with each other and with the amount of dry shellac used, at least if nothing less volatile than ethyl alcohol is in the solvent. The weights of the residues from the shellac varnishes containing less volatile solvents are in approximately the same order as the end-point temperatures of the solvents used. That the use of the most volatile solvent (the proprietary one) resulted in the recovery of slightly less than the weight of dried bleached shellac used is not surprising in view of the fact that the addition and subsequent evaporation of a very volatile solvent has long been in use for the removal of less volatile material from very viscous and colloidal material in general. The fact that triplicate tests of the same varnishes by the FS method gave slightly more concordant results than by the ASTM method may make it preferable. Its greater convenience and simplicity are additional and probabiy more important reasons for using it.

Because the amount of volatile material in dry shellac varies, it is impossible to determine by analysis the exact weight of the dry shellac that was cut in a gallon of solvent. However, the analyst can obtain an approximate value for the cut by making a positive correction on the nonvolatile residue, using arbitrary values for the volatile content of the dry shellac. The arbitrary values found to be most satisfactory for this estimation are 1.4 percent for orange shellacs and 4.2 percent for bleached shellacs.

Specifications to be significant should state the percentage of nonvolatile material in a shellac varnish, dried at $105^{\circ} \mathrm{C}$, as the Government specifications do, and not the cut of the varnish.

Appreciation is expressed to members of the Bureau's paint section for their helpful advice, and to Wm. H. Gardner, of the Shellac Research Bureau, Brooklyn, N. Y., for furnishing representative samples of bleached shellac. 


\section{REFERENCES}

[1] Official Methods of Analysis, Specifications, and General Information on Shellac and Bleached Shellac, Approved by the U. S. Shellac Importers Assoc., Inc., and the American Blearhed Shellac Manufacturers Assoc., Inc., N. Y. The United States Shellac Importers Assn., Inc., New York, N. Y. (1934).

[2] C. C. Hartman, BS J. Research 7, 1105 (1931) RP391.

[3] Book of Standards, 1939, part 2, Nonmetallic Materials, Construotional. American Society for Testing Materials, Philadelphia, Pa. (1939).

[4] Federal Specification for Varnish; Shellac. U. S. Government Printing Office, Washington, D. C. (May 26, 1931).

[5] Formulae for Completely and Specially Denatured Alcohol, Appendix No. 3 (1938). U. S. Bureau of Internal Revenue. U. S. Government Printing Office, Washington, D. C. (1939).

Washington, May 15, 1940. 